\title{
Vanke Real Estate Debt Financing Structure's Impact on Firm Performance
}

\author{
Ma Xiaoxue \\ Shaanxi Normal University \\ Xi'an, Shaanxi China, 710062 \\ mushroom99@foxmail.com
}

\begin{abstract}
Debt financing is one of the necessary ways to obtain funds under the condition of continuous and rapid economic development. However, this method of obtaining funds will also bring hidden dangers when it brings certain benefits to the company or the company. Under the strongest and most stable favorable conditions of capital and assets, enterprises will bring the greatest benefit to the enterprise. The real estate industry is one of the major industries in China. The research is based on Vanke Real Estate and theoretical exploration of the profitability or loss of debt financing, and finally makes suggestions for the development of Vanke Real Estate.
\end{abstract}

Keywords-Real estate industry; Debt financing; Firm Performance

\section{INTRODUCTION}

The research on the value of Chinese real estate brands has been going on for seven years since 2004. The theoretical system has been continuously improved, the research fields and achievements have been continuously deepened, and it has aroused widespread concern from all walks of life. At present, China's real estate industry is mainly faced with the following problems: 1. China's real estate industry is facing an unprecedented adjustment; 2. The future uncertainty of the Chinese real estate industry is greatly improved; 3 . The world economy and the world real estate market continue to slump; 4. The pressure of sustainable growth and the pressure of inflation remain high in China's economy [1-3].

The real estate industry is an important part of the entire national economy. It is in a pivotal position in the national economy. It is closely related to the development of the economy and has a close connection with it. Since the reform and opening up in 1978, Deng Xiaoping issued a series of policies and measures to promote the rise of the real estate industry. The urban economic system reform implemented in 1985 directly realized the direct development of China's real estate industry. The state has also relatively issued a series of regulations, such as "Real Estate Economic Development" and "Notice on Strengthening Real Estate Market Management" to improve the market order, regulate the development of the real estate industry, and improve the integration of the real estate industry [4-5]. At the beginning of the period, generally implemented in accordance with national policies, the establishment of public housing and urban housing, there is no private house, with the adjustment of the country's macroeconomic policies, the purchase or construction of housing with individual property rights gradually popularized. However, China's current real estate market development level and the degree of standardization need to be further improved and presented. The reality requires us to solve the problem without delay and meet the market economy real estate industry as soon as possible.

\section{REAL ESTATE DEBT FINANCING ANALYSIS}

\section{A. Real estate development}

With the constant increase of China's economy, and the continuous improvement of comprehensive strength and technology, China's real estate market is also rapidly developing in the market.

\section{1) Investment maintains a fast development trend}

Since 2006, the total real estate nationwide has reached $1,938.2$ billion yuan, an increase of $90 \%$ compared with the same period last year and an increase of $28 \%$ compared with the same industry. In the first quarter of 2010, the total amount of real estate projects completed reached 354.378 billion yuan, an increase of $26.9 \%$ compared with the same industry, an increase of $6.7 \%$ as compared to the original, which is greater than the $1.6 \%$ of urban and township investment in the same period. The proportion of real estate development in the eastern, western and central regions was $64 \%, 17.8 \%$, and $18.2 \%$, respectively [6]. In the first quarter of 2010, the East, West, and Central regions also rose by $24 \%, 36.3 \%$, and $29.6 \%$. The capital in the central region is greater than in the eastern part of the country. The real estate industry is still the main force of our country. The growth of accumulated funds is also a strong force of the real estate industry. The total investment in real estate accounts for a total of less than $21 \%$ of the total fixed assets in the countryside [7-10].

2) Rapid growth of land area for sustained development

Since 2006, the development of China's real estate industry has grown substantially. The negative state of low speed has been declining for two consecutive years. In 2010, the total land area for real estate development reached 266,060,000 square meters, an increase of $18 \%$ from the previous period and an increase of $40.3 \%$ compared to the previous year. In the period from February to June this year, the land area for real estate development nationwide was 78.15 million square meters, an increase of $5.6 \%$ over the same period. The country 
has introduced new policies and regulations, and the idle period of idle land for enterprises is subject to an increase in fees, which will be confiscated within two years or more. Therefore, it is difficult for developers to develop policies and have to use limited time limits to avoid the loss of development-purchased land. In 2010, the area purchased was 390 million square meters, which was a decrease of $4.8 \%$ over the same period, which was higher than in previous years.

3) An important source of real estate investment is domestic loans

The "2004 China Real Estate Finance Report" shows that the People's Bank of China clearly stipulates that about $70 \%$ of the funds raised by the company come from bank loans, of which more than $30 \%$ of the funds for housing deposits and advance receipts come from banks. In the process of real estate development, the proportion of bank loans accounts for more than $55 \%$, and the personal loan amount is generally between $40 \%$ and $50 \%$. Excessive supply of real estate and low demand will lead to a sharp decline in real estate prices. This is an unfavorable condition for commercial banks, and the amount of unreturned loans will also increase.

4) The amount of land purchased by real estate developers has been increasing

There have been large and small problems in China's land transaction issues. The supply of real estate has been disorderly and long, especially when it rose by $18.3 \%$ in 1999 , by $14.4 \%$ in 2000 , by $38.5 \%$ in 2001 , and by $38.1 \%$ in 2002 ., an increase of $40.5 \%$ in 2003 , these figures are higher than the growth rate of real estate development in the same period. About 30,000 real estate development companies across the country all actively invest in activities that lead to the purchase of land ahead of schedule. The trend that hinders the development and utilization of land resources in China is not conducive to sustainable development.

5) Housing security system and real estate management policies are incomplete

In recent years, the construction of the housing security system in the real estate market regulation and control policy has always been an important component. However, due to the lack of motivation for the construction of the housing security system by local governments, and the incomplete implementation of late-stage funds, together with other external factors, there are still some problems in the speed of the construction of China's housing security system, and the development is also very slow. At the same time, unsound business models and management systems also cause a series of negative behaviors for real estate buyers and developers. The above behavior has led to the healthy, continuous and methodical continuous development of real estate in our country, directly affecting the rise and development of people's living standards.

\section{B. Debt financing}

\section{1) The concept and role of debt financing}

Debt financing refers to the most useful way for an enterprise or company to obtain funds. Specifically, it carries a certain amount of debt to raise funds. Providers of funds have the right to recover capital and interest, and achieve income within a certain period of time. The inevitable reason for enterprises to obtain funds is that in the case of a certain amount of debt financing, debt financing can directly indirectly benefit the company while meeting the company's capital requirements. Debt financing mainly has the following effects:

(1)It has the effect of taxing interest. The most important feature of the debt is to bring certain tax benefits to the company, that is, the interest of the debt can be deducted from the profit before the tax, resulting in a reduction in the amount of taxable income that brings about a certain value improvement effect to the company or company.

(2)It has the role of financial leverage. Debt holders have certain ownership rights and fixed claims for the company's funds. If the company has certain benefits, it is also very favorable for creditors, but only a part of the stable interest income, huge and huge benefits will all be given to shareholders, so that the earnings per share also increased.

(3)It can reduce frictions and conflicts between managers and shareholders. As the company's efficiency increases, the number of external shareholders increases, and the company's internal shareholders will have slack. Therefore, for their own interests, shareholders will bring moral hazard to the company and affect the efficiency of the enterprise. Debt financing can solve the contradiction between managers and shareholders, so that the two can be mutually controlled to maximize the interests of the company.

\section{2) The Status of Debt Financing Level of Real Estate} Listed Companies

In 2010, the debt ratio of China's real estate was generally higher than the end of 2008 and 2009. In 2008, among 90 real estate development and listed companies, there were 60 companies with debt ratios between $50 \%$ and $80 \%$, of which 15 companies, 26 companies, and 17 companies had assets and liabilities of around $55 \%, 63 \%$, and $75 \%$ respectively. The acquisition of debt funds of listed real estate companies in China comes from the following aspects:

(1) Long-term borrowings and short-term borrowings are obtained by borrowing money from financial institutions and non-financial institutions.

(2) Accounts payable and advance receipts earned during the development process are due to product, technology, and labor settlement.

(3) Other payables.

(4) Individual companies implement liabilities formed by corporate bonds.

The real estate financial market system in China is now in an imperfect state. Coupled with the real estate company's own funds, it is difficult to increase significantly in a short period of 
time. The occupation of real estate funds and the long time spent also affect the real estate company's debt level.

\section{VANKE REAL ESTATE}

\section{A. Vanke Real Estate Financial Policy}

From 2003 onwards, in order to reduce the boom in real estate investment, the prices of commodity buildings have also increased rapidly. China has issued many regulatory measures in terms of land and financial policies, and the fund-raising model has thus been greatly affected. For example, on April 27 2004, the amount of real estate capital in the country's switch, which accounts for the proportion of the total, requires a retreat. The development of real estate from the original greater than or equal to $20 \%$ increase is greater than or equal to the original $35 \%$, and then to adjust the ratio in May 2009. Among them, the funds for affordable housing and ordinary commodity housing projects have been restored to the level of 1996, and the proportion has been reduced from $35 \%$ in 2004 to $20 \%$. Compared with other real estate projects, $30 \%$ is the lowest limit, and the increase in credit in 2009 was due to the increase in other forms of financial credit.

\section{B. Vanke Real Estate Financial Policy}

The financing of real estate companies affects the financial market system. The real estate financial system in developed countries is affected by the primary and secondary markets. A stable market will give more choices. Apart from China's real estate finance, it is still at the primary level, and therefore it limits the fund-raising parties of real estate companies. For example, the imperfections in the bond market have kept the level of financing low, removing the channel of stock market financing, real estate companies meeting their capital needs, and as long as they rely on bank loans, this can also improve real estate listed companies.

\section{IMPROVING VANKE REAL ESTATE DEBT FINANCING MEASURES}

\section{A. Further adjust the investment structure of commercial housing development}

In accordance with the residents' income levels and prices, develop different real estate projects of different grades and increase ordinary commercial housing. In the control of the construction of high-end residential or commercial housing, the standards for the classification of high-grade commercial housing and ordinary housing should be reasonably determined according to the actual situation in each place. For high-end, large-sized commodity housing, and high-end office buildings, where there are a large number of commercial users, it is necessary to control the construction of such projects, and can also appropriately improve the pre-sale conditions and the proportion of funds for high-end commercial housing development projects. Therefore, the government will also increase its efforts to increase the housing area.

\section{B. Strengthen management and standardize the order of real estate development market}

First of all, the approval, planning and quality inspection of the development of commercial housing in residential areas shall be intensified to prevent the implementation of unhealthy conditions and failure to meet the conditions for development, so as to ensure order and harmony in the real estate industry. The real estate departments have stepped up inspections and vigorously implemented a series of policies to curb unfair behavior in real estate.

\section{Strengthen credit management and prevent capital risks}

In order to ensure sustained and steady growth of funds, the government should introduce a series of measures to reduce the tax rate to provide convenience to developers.

\section{Improve the land transfer publicity system and strengthen management of land supply planning}

The government should formulate a scientific land supply and demand plan and implement a public announcement system as soon as possible according to the supply and demand conditions of the real estate market, so as to effectively regulate the market supply and demand situation. In addition, it belongs to the newly prepared land annual supply plan, according to the actual situation of the country, to produce a reasonable policy.

\section{CONCLUSION}

First, China Vanke Real Estate Corporation's debt financing structure has a positive correlation with corporate performance. In recent years, the real estate industry has relied mainly on loans from banks and other financial industries, so it is a great support for the real estate industry, and the real estate industry has experienced a boom. In addition, the use of debt in the form of a better tax savings, but must take into account the bankruptcy costs, so the company must have a strong control over the proportion of debt.

Second, there is a positive correlation between the financial performance of real estate companies or companies and the company's asset structure. However, the development and growth of a company are not easily affected by corporate performance. It is precisely because the prototype of the real estate industry in China is relatively weak. The management, operation, and development of real estate companies are all in a less mature and stable state. Therefore, in the later management structure, the energy and cost that will be required will be higher. In addition, under the general circumstances of obtaining funds for growth investment opportunities and fundraising methods, they only rely on bond-based fundraising, which is generally bank credit. There are also uncertain factors, such as: not very good liquidity: greater commercial risks and pressures, it is not easy to get more policy support.

Third, the company's operating performance has a number of factors, among which the company's own internal finance is a cause. However, the political and economic measures, industry factors, and the company's own business are all important factors. Second, the company's operating performance will also be affected by the company's ownership 
of the company's equity, structural ownership, and other aspects. The main research of this dissertation is to explore the relationship between Vanke Real Estate's debt financing structure and the performance of the company, which also influences the conclusion of this paper.

\section{REFERENCES}

[1] Li Guangyu. Research on Financial Management of Real Estate Development Enterprises [D]. Southwestern University of Finance and Economics, April 2007.

[2] Wang Xinfang. Research on cost control of real estate development [D]. Xi'an University of Science and Technology, February 2008.

[3] Ning Qiong. Relationship between ownership structure and governance performance of real estate listed companies [D]. China Real Estate, November 2010.

[4] Wu Caihong. Performance Evaluation of Real Estate Listed Companies in China [D]. Full-text Database of China's Outstanding Master Degree Theses, December 2008.

[5] Yan Song. Performance evaluation of real estate listed companies and analysis of influencing factors [D]. China's Outstanding Theory is a dissertation full-text database August 2010.

[6] Wei Sai. Comparison and selection of real estate financing methods [D]. Southwestern University of Finance and Economics, April 2007.

[7] Xue Ying, Wang Chunfeng. Innovation of Real Estate Financing Methods in the International Market and Financing of China's Open Market [J]. Modern Finance and Economics - Journal of Tianjin Finance and Economics Institute, February 2010.

[8] Ren Huaixi. Analysis of current real estate industry problems and countermeasures $[\mathrm{J}]$. Accreditation of High Teaching Journal, February 2013.

[9] Lin Yifu. Current real estate prices in China, a new solution to the bubble [N]. China Youth Daily, December 2010.

[10] Wu Yuanqi, Zhou Yezhu. Public decision-making system and policy analysis [M]. Beijing: National School of Administration Press, 2003. 